\title{
Quantifying airtightness in Brazilian residential buildings with focus on its contribution to thermal comfort
}

\begin{abstract}
Airtightness refers to the amount of air leakage through a building's envelope. This uncontrolled exchange of air between inside and outside, either infiltration or exfiltration, may lead to thermal discomfort. Nevertheless, little or no attention has been given to airtightness in some countries including Brazil. In Brazil, a range of different strategies are suitable to achieve thermal comfort depending on the several climatic regions. In those regions where winter conditions are noticeable, such as in São Paulo, airtightness is a key parameter, but it has been historically overlooked. In this work, the authors deployed the innovative Pulse test methodology to determine airtightness levels for the first time in Brazil, in the city of São Paulo. Three representative multifamily residential buildings dating from the 1970's, 1980's and 2000's were measured, and the results' values widely ranged from $1 \mathrm{~h}^{-1}$ to $5.7 \mathrm{~h}^{-1}$, at $4 \mathrm{~Pa}$. Next, dynamic building simulations were conducted using measured and representative airtightness values (converted to infiltration) to understand the contribution of this variable on the thermal comfort. The results suggested that up to $9 \%$ improvement in the thermal comfort levels could be achieved by adopting $1 \mathrm{~h}^{-1}$ as maximum infiltration, and up to $14 \%$ by adopting $0.5 \mathrm{~h}^{-1}$.
\end{abstract}

Keywords: airtightness; infiltration; Pulse test; thermal comfort; multifamily residential buildings.

\section{Introduction}

Airtightness refers to the amount of leakage paths where air can pass through a building's envelope, measured in various units. Airtightness plays an important role in the delivery of thermal comfort and energy efficiency, in a range of different climates (Emmerich et al., 2005). Its recognised impact has led to the progressive introduction of target values in various countries, set in place to improve thermal comfort and energy efficiency in buildings (Building Research Establishment, 2013; Etheridge, 2015; Khemet \& Richman, 2020; Love et al., 2017; Mortensen \& Bergsøe, 2017; Prignon \& Van Moeseke, 2017; Santamouris \& Asimakopoulos, 1996). In the United Kingdom (UK), airtightness targets (or, more specifically, air permeability as this is the metric used) appeared first in the regulations in 2002 (HM Government, 2002), and testing became a mandatory requirement under Building Regulations Part L in 2006 (HM Government, 2006). 
Airtightness is measured through steady state pressurisation tests. The most common test is known as the blower door testing, which measures the air leakage rate per hour per square metre of building envelope area at a reference pressure differential of 50 Pascals. This involves mounting a 'door' with an incorporated fan, into the frame of an external door opening, used to vary the pressure in the building. The resulting difference between the pressurisation and depressurisation is then used to calculate the permeability of the building envelope. Because this type of testing significantly impacts on buildings' occupancy, talking hours to be prepared and performed, much work on the airtightness field has been focused on the development of innovative airtightness measuring tests and representations. One of such tests is the Pulse method (E. Cooper et al., 2016; Zheng et al., 2019), a simple, quick and accurate test undertaken using a portable compressed air based system. Because it measures leakage at a lower pressure, the system provides a better representation of normal inhabited conditions, helping to improve understanding of energy performance, thermal comfort and ventilation needs. The whole test process takes under a quarter of an hour, can be undertaken by one person and is much less invasive than a blower door test for the occupiers. Because of its portability, simplicity of use and accuracy, this system was used for the development of this work.

Despite the advances in the airtightness knowledge, its importance has progressed distinctively among countries, mostly due to their different climatic contexts, cultural influences and levels of development (Patrascu et al., 2018). It is common that countries of subtropical or tropical climates, such as Mexico and Brazil, overlook the concept and do not measure airtightness levels neither evaluate their impact on thermal comfort in buildings. In these generally warmer countries, ambient conditions are mostly within an acceptable thermal comfort range of temperatures, and the largest proportion of buildings are naturally ventilated. In naturally ventilated buildings, the relevance of airtightness become less evident as the flow of air through the envelope is considerably smaller in comparison to the ventilation rates. In these climates, there are not enough studies covering the contribution of airtightness on the thermal comfort (Fernández-Agüera, Domínguez-Amarillo, Alonso, et al., 2019; Ford et al., 2007; W. Ji et al., 2018; Tubelo, 2016; Tubelo et al., 2018).

In Brazil, the concept of airtightness is neglected despite the variety of climates found and requirements to use different strategies to achieve thermal comfort. In São Paulo, southern Brazil, where this study was conducted, the climate is subtropical with warm summers and cool winters (Cfa, according to 
Köppen classification). Residential buildings are predominantly naturally ventilated, but the use of air conditioning has been growing significantly. In climates of this kind, due to the significant winter conditions/or recognised cooler temperatures during winter, an airtight building may be appropriate, even though the idea of an airtight building envelope with sealed windows feels contrary to the cultural habits of naturally ventilated buildings (Pacheco \& Lamberts, 2013) and preferences for air movement (Candido et al., 2011). The benefits of airtight buildings may be more obvious in the winter period when ambient conditions are mostly below the comfort levels and during heat waves in the summer period, when extremes of temperature occur and the external conditions get unfavourable to the use of natural ventilation to improve comfort levels.

In this work, the authors deployed the innovative Pulse test to measure the levels of airtightness of multifamily residential buildings in São Paulo, Brazil, for the first time. The originality of the work lies on the use of this innovative test method, on the collection of airtightness values for the first time, and in the exploration of the contribution of this design parameter to comfort in buildings in this location. The study was structured in two parts. The first part consisted of measuring the airtightness values in representative case study buildings using the Pulse method and reporting on its meaning. The second part consisted of using analytical work developed through dynamic building simulations. Various levels of airtightness (converted to infiltration levels) were adopted as the varying parameter in a sensitivity analysis that measured their impact on comfort levels.

This work did not survey a large sample of dwellings due to project constraints. Instead, a detailed assessment of 3 selected case study buildings was undertaken, and this will join a larger body of work under development by the team. The objective of the evaluation of the different case study buildings was not to compare their performances, given their different design and construction features, but to provide an overview of representative residential building typologies and their associated thermal and airtightness performances in the climatic context of the city of São Paulo. The work methods and findings are relevant to building design, simulation, and construction in a number of cities in the subtropical climate zones, and more widely to research in the field of airtightness.

\section{São Paulo}

São Paulo has a population density estimated to be $7,398.26$ hab/ $\mathrm{km}^{2}$ as per 2010 census (IBGE, 2017). The city was ranked $10^{\text {th }}$ out of the 5570 Brazilian municipalities in density and $1^{\text {st }}$ in absolute 
population (IBGE, 2017). Due to the city's high population density, its most common housing typology is apartments, particularly in the inner city. This typology accounts for a significant percentage of the city's housing stock; only between 2005 and 2014, 96\% of the housing units launched in São Paulo were part of apartment developments (Alves, 2019) and, thus, this typology was selected for this study.

\section{Climate}

The climate of São Paulo is subtropical humid (Cfa according to Köppen classification) with warm humid summers and cool and drier winters, annual average temperatures of $19.1^{\circ} \mathrm{C}$ and annual average minimum and maximum temperatures ranging from $10.7^{\circ} \mathrm{C}$ to $31.1^{\circ} \mathrm{C}$ (Alves et al., 2016). Monthly averages of relative humidity do not exceed $80 \%$, average maximum and minimum relative humidity are in January (75\%) and July (61\%), respectively (Roriz, 2012). Figure 1 shows the annual distribution of temperature and relative humidity in São Paulo, based on Roriz (2012).

São Paulo's climate is generally mild and comfortable, but in recent years it has become more extreme due to climate change and heat island effect (Alves, 2019). Average annual temperatures have increased by approximately $3^{\circ} \mathrm{C}$ and the average annual relative humidity levels have reduced to $80 \%$ in less than a century of measurements (Alves, 2019). Studies on urban heat island in São Paulo, have showed a temperature gradient of $6^{\circ} \mathrm{C}$ to $8^{\circ} \mathrm{C}$ among areas with different degree of urbanisation (Oliveira et al., 2018).

January is the hottest month, with an average temperature of nearly $23^{\circ} \mathrm{C}$, absolute minimum and maximum temperatures reach $14^{\circ} \mathrm{C}$ and $37^{\circ} \mathrm{C}$ (INMET, 2018), respectively, whilst the relative humidity varies between $31 \%$ and $100 \%$ (Uzum \& Gonçalves, 2020). July is the coolest month, with an average temperature of nearly $17^{\circ} \mathrm{C}$, absolute minimum temperature of nearly $1^{\circ} \mathrm{C}$ and absolute maximum temperature of $30^{\circ} \mathrm{C}$ (INMET, 2018), whilst the relative humidity varies between $26 \%$ and $100 \%$ (Uzum \& Gonçalves, 2020). In typical cooler/mild days, the temperatures can reach as high as $24^{\circ} \mathrm{C}$, or slightly higher, because of solar radiation, whereas in a cooler cloudy day, air temperatures hardly rise above $15^{\circ} \mathrm{C}$.

\section{Building occupant's behaviour}

Brazilian residential buildings are predominantly naturally ventilated, and this is particularly the case in São Paulo. In summer, windows are kept open when possible regardless of outdoor temperatures. The 
use of air conditioning units, which are mostly installed in bedrooms or/and living rooms, are common (and growing) in middle- to high-income households. The electricity consumption for household air conditioners more than tripled in 12 years according to 2017 data and its electricity demand is estimated to increase 5.4\% per year until 2035 (EPE, 2018). This trend might worsen with climate change as the projections for the region indicate a rise in temperatures of between $0.5^{\circ}$ and $1^{\circ} \mathrm{C}$ by 2040 and a gradual rise between $1.5^{\circ} \mathrm{C}$ and $2^{\circ} \mathrm{C}$ by 2070 (PBMC, 2013).

In winter, the inappropriate use of windows and ventilation by the occupants can greatly affect thermal comfort, but it is also the uncontrollable air leakage that impacts on the indoor thermal comfort as the cold air enters the building by cracks and gaps within the envelope. The most common alternative to achieve thermal comfort is the use of inefficient portable heating devices, but also the use of air conditioning with the heating function.

Even though the use of heating and cooling devices in residential buildings is still somewhat limited in Brazil (Alves et al., 2016), the rise in income and standard of living are expected to raise the numbers of households that utilise these devices as this will be within their economic reach (EPE, 2018; Ghisi et al., 2007; Triana et al., 2018). Mitigation strategies should be considered accordingly, specially solutions that can increase indoor thermal comfort by passive means or using the lowest possible amount of energy (Alves et al., 2016). In this sense, the technical work presented here investigated the extend by which controlling air permeability can improve indoor comfort, particularly during the cooler and hotter periods of the year in São Paulo.

\section{Thermal comfort acceptability and criteria}

Adaptive comfort models are based on the premise that people can adapt to make themselves more thermally comfortable in naturally ventilated buildings and thus, the user is no longer seen as passive to the surrounding environment, but as the controller of it (Humphreys et al., 2013; J. Nicol et al., 2012). The adaptation can vary widely, such as through varying the clothing levels, the operation of windows for ventilation or the use of fans to increase air speed.

Thermal comfort limits were calculated using ANSI/ASHRAE Standard 55 (2010) considering 90\% of acceptability by the occupants and taking São Paulo's average monthly temperatures as reference (Figure 2). The comfort limits were calculated to be $20-27^{\circ} \mathrm{C}$ throughout the year and broader comfort 
temperatures were also demonstrated in Figure 2 for reference purposes, representing a higher degree of acceptability by the occupants.

Adaptive comfort models overlook the effect of humidity on occupants' comfort. It is known that higher humidity level (relative humidity and/or absolute humidity) slightly decreases upper comfort temperature limit, however, the extension of it is considered limited (F. Nicol, 2004; Parkinson et al., 2020; Rijal et al., 2015). Prior research indicates that absolute humidity lower than $15 \mathrm{~g} / \mathrm{kg}$ would not impact the thermal comfort limits in naturally ventilated buildings (Givoni, 1992). Research in humid climate or in conditions when the relative humidity is high, people may require temperatures that are just about $1^{\circ} \mathrm{C}$ lower to remain comfortable (F. Nicol, 2004). Psychrometric chart of São Paulo, created using Analysis Bio Software (LabEEE, 2010) and climate data (Roriz, 2012) shows that absolute humidity is lower than $15 \mathrm{~g} / \mathrm{kg}$ and it is not an issue in this climate (Figure 3).

\section{Airtightness in buildings}

Airtightness is the property of how well a building is 'sealed'. There are different metrics to measure airtightness; one being air permeability, as used in the UK regulation, is defined as the rate of leakage per area across the envelope, given in $\mathrm{m}^{3} \mathrm{~h}^{-1} \mathrm{~m}^{-2}$. The other metric being when flow $\left(\mathrm{m}^{3} / \mathrm{s}\right)$ is not normalised by volume and envelope area and is given as an overall building air change rate, expressed in $\mathrm{h}^{-1}$.

Airtightness for regulatory purposes in the countries that have airtightness requirements is currently measured by means of the steady state pressurisation method alias blower door testing. The steady state test is conducted by means of a fan installed within an opening of the building envelope. The fan can either pressurise or depressurise the building and air flow rate is measured at points across a range of pressure difference typically from 10 to 60Pa (BS EN ISO 9972, 2015). The airtightness, or air permeability of a building is then quoted at a specific pressure difference, which varies in different countries, e.g. UK regulation requires air permeability to be quoted at $50 \mathrm{~Pa}$ pressure difference $\left(Q_{50}\right)$.

Even though airtightness is a relatively new topic for the practice of building design and construction in countries such as Brazil, it has been widely studied elsewhere since the 1970's. Airtightness measuring methods such as the steady pressurisation method (blower door) has been deeply investigated (Chan et al., 2005; M. Sherman \& Palmiter, 1995) and internationally standardised (ASTM, 2019; BS EN ISO 
9972, 2015). Despite its development, the steady pressurisation method has shortcomings such as measuring airtightness at an elevated (artificially created) pressure difference regarded as not representative of natural building conditions, or modifying the building envelope by mounting a door frame in an original doorway. Acoustic (Hassan, 2013; lordache \& Catalina, 2012; Varshney et al., 2013), infrasonic (Watanabe et al., 1999) or decay (Mattsson \& Claesson, 2007) methods to determine airtightness levels have also been tested. More recently, the Pulse method has been investigated ( $E$. Cooper et al., 2007; E. Cooper et al., 2016; Zheng et al., 2019).

The Pulse method is a low-pressure self-contained device which can be implemented within the building enclosure, hence not modifying it. Nevertheless, it does not have the capacity of leak detection. The impact on airtightness of stack effect, wind, barometric pressure, or other conditions has been investigated (Kraniotis et al., 2014; Patrascu et al., 2018; M. H. Sherman, 1987, 1991) and conclusions show that when high wind speed is present, it is difficult to measure airtightness at low-pressure using the steady pressurisation method (M. Sherman \& Palmiter, 1995).

Airtightness mainly determines the infiltration rate of a building under certain environmental conditions. Therefore, how airtightness relates to infiltration via air infiltration models has been investigated (Jones et al., 2014; Orme \& Leksmono, 2005; M. Sherman \& Dickinson, 1985; Walker \& Wilson, 1990). Furthermore, the mathematical representation of air exchange in buildings has also been investigated and two formulations have been tested, a power law and a quadratic equation (Chiu \& Etheridge, 2002; Walker \& Wilson, 1998); though more recent studies using an extended power law have been carried out (Baracu et al., 2017).

Finally, with the intention of aiding policy makers to provide airtightness standards, characterisation of buildings in terms of airtightness levels have been carried out in countries such as Finland (Vinha et al., 2015), Spain (Feijó-Muñoz et al., 2019; Fernández-Agüera et al., 2016; Fernández-Agüera, Domínguez-Amarillo, Sendra, et al., 2019) or Portugal (Ramos et al., 2015; Salehi et al., 2017). For illustration purposes, airtightness requirements in different countries are listed in Table 1, adapted from RDH Building Engineering Ltd (2013). 
In order to establish a reference to the Brazilian context, the airtightness levels were calculated (last two columns of Table 1) using the typical Brazilian social housing dimensions ( $6 \mathrm{~m}$ by $6 \mathrm{~m}$ of floor plan, $2.50 \mathrm{~m}$ of floor-to-ceiling height, $90 \mathrm{~m}^{3}$ of volume and $132 \mathrm{~m}^{2}$ of envelope area), as set by Ministério das Cidades (2014) and showed in Tubelo (2016). Even though the case studies presented in this work do not represent a typical social housing typology (as middle-class multi-storey residential buildings, such as the ones selected for these studies, greatly varies in volume and envelope area), this was adopted for reference purposes.

This information should, however, be carefully handled because the use of different units can lead to different results, i.e. when ranking buildings depending on the airtightness, if $\mathrm{m}^{3} \mathrm{~h}^{-1} \mathrm{~m}^{2}$ is used as a unit, one obtains a different order in the rank than the one obtained using $\mathrm{m}^{3} / \mathrm{s}$ or $\mathrm{h}^{-1}$ as unit (Y. Ji \& Duanmu, 2017). It should be noted that the conversion performed for the data in the last two columns was made using Equation 1, where $C$ and $n$ are flow constant and exponent, $Q_{i}\left(\mathrm{~m}^{3} / \mathrm{s}\right)$ is the flow at the $i$ pressure difference $\Delta P(\mathrm{~Pa})$, and assuming that the flow exponent ( $n$, dimensionless) is equal to 0.66 , a representative value of flow through adventitious openings (Orme \& Leksmono, 2005). C can be calculated from the measured $Q$, the known $\Delta \mathrm{P}$ (4 for Pulse, 50 for blower door tests) and the assumed or measured flow exponent. Once again, one must be careful using this assumption, this value can vary from place to place, and the information presented can only be used for comparison between codes. Nevertheless, this exercise has been useful to show the wide variance of values even across similar climates.

$$
\begin{aligned}
& \text { Equation 1: } \\
& \qquad Q_{i}=C \Delta P^{n}
\end{aligned}
$$

As discussed, airtightness testing provides a metric to establish how 'leaky' a building is; however, this value does not directly represent the transfer of air in and out of the building at ambient pressure differentials. The non-intended flow of air from or to the outdoor of the building in the ambient condition can be called infiltration or exfiltration depending on the direction of the flow. Air infiltration is mainly dependant on airtightness, the main difference is that the first one changes with environmental conditions, such as wind speed and temperature difference; and the latter can be considered as a property of the building fabric, which does not change in the short term, unless human action is applied (for example, interventions to the building fabric such as drilling holes for services). 


\section{Airtightness in Brazil}

In Brazil, there is neither airtightness requirement nor test available to measure the airtightness levels in buildings (Lamberts, 2008). The only reference for airtightness in the country has been published in the Brazilian standard NBR15575 (ABNT, 2013a, 2013b, 2013c). This reference, expressed as infiltration, is for use solely in dynamic building simulations and corresponds to an infiltration rate of 1 $\mathrm{h}^{-1}$ at ambient pressure. It is unknown, however, whether this value applies to new buildings only, is related to a specific building type or whether this is a representative value of Brazilian buildings.

There is also uncertainty about the delivery of the recommended building infiltration levels due to the traditional handcrafted nature of the overall Brazilian construction. The Brazilian construction is heavy and robust with the use of brick and ceramic and concrete blocks, but it has a high construction variability. On one hand, interiors are usually plastered, and slabs are made of in-cast concrete in most of multifamily residential buildings, a characteristic that contributes to achieve greater levels of airtightness. On the other hand, windows are fitted to the envelope without considerably attention to airtightness and thermal bridges. On the top of that, services are executed within walls and slabs without much attention to the integrity of the envelope, features that impair the airtightness levels delivered.

Very limited number of studies in Brazil have looked at infiltration rates and its impact on thermal comfort (Pacheco, 2013; Pacheco \& Lamberts, 2013; Tubelo et al., 2018). These studies, however, focused on simulating different levels of infiltration and did not include actual measurements.

Pacheco (2013) evaluated the thermal comfort of an insulated and airtight housing under natural and mechanical ventilation systems, in subtropical and equatorial Brazilian climate zones 1 (Curitiba) and 8 (Belém), respectively. For the subtropical climate, results suggested that the lowest thermal transmittance building envelope had simultaneously the lowest and highest annual sums of heating degree-hours, depending on the shading type adopted. The study, however, focused on the delivery of thermal comfort by looking exclusively at the thermal transmittance of the building envelope, combined with very low airtightness levels equivalent to the Passivhaus standards (0.6ach @ 50Pa) and did not evaluate the contribution of varying airtightness levels.

Tubelo et al. (2018) conducted a parametric study using a single-family 1-storey 2-bedroom housing typology and investigated two different infiltration rates $\left(1 \mathrm{~h}^{-1}\right.$ and $0.15 \mathrm{~h}^{-1}$ at ambient pressure) for 
different building envelope combinations, varying their insulation levels in the subtropical Brazilian climatic zones 1 (Curitiba) and 3 (Porto Alegre and São Paulo). The findings revealed that limited infiltration rates on typical building envelope combinations increased the thermal comfort by up to $25 \%$ throughout the year. However, limited infiltration rates were shown to be more beneficial when adopted on super-insulated envelopes, improving thermal comfort by up to $97 \%$ for a thermal comfort band reference of $20-25^{\circ} \mathrm{C}$.

\section{The case study buildings}

The aim of this work was to select representative apartments in multifamily residential buildings in the city of São Paulo, to firstly measure the levels of airtightness delivered by their building envelopes and secondly explore the impact of these levels on the delivery of thermal comfort.

The case study apartments have distinct building typology, orientation, floor area, volume, windows-towall ratio, year of construction, exposure to the environment, and were built using different construction components (Table 2, Table 3 and Table 4). All the buildings are located in densified urban sites of the city of São Paulo and the apartments' levels were similar ( $2^{\text {nd }}$ to $4^{\text {th }}$ floors $)$.

As mentioned, the aim of evaluating different and representative case study buildings is not to compare their airtightness values and resultant thermal performance against each other, given their different design and construction features, but to provide an overview of different typologies, a range of airtightness levels found and then, their thermal comfort contribution in the context of São Paulo. Also, it should be noted that it is not scope of this paper to explore the impact of tall and wind exposed buildings, but it is to establish current values contemplating a larger number of examples that consist of multifamily buildings of up to 4 floors.

Multifamily residential buildings are especially predominant in larger cities and started to appear in São Paulo in the 1970's (Veiga \& Burgarelli, 2016). It is estimated that out of the 3 million buildings in São Paulo, one quarter date back from the 70's and one fifth date back from the 80's (Veiga \& Burgarelli, 2016), which demonstrates the significance of buildings of this era in the city

The apartment in Higienópolis, built in the 1960's, is the largest. Almost all its facade is made up of glass and steel frame, in which gaps between windows were observed. The apartment is expected to be less airtight due to the poor condition of the window frames and the closing mechanism of the 
windows. The building is one of the icons of the bioclimatic modernist movement of the Brazilian architecture that considered shading, solar access and ventilation for the comfort of the occupants (Serapião, 2014). The elements of this architecture are considered to be reference of good environmental performance on the top of its great relevance within the Brazilian architectural context.

The apartment in Pinheiros, part of a low-income housing scheme from the 1980's that in the end was put to the market, is occupied by middle-class family. The original wooden-frame windows were changed for aluminium frame ones, as it has happened to a great number of flats of this type in the past decades, around the city. Despite the age of the building, the construction is in good visual condition. The building was built within one of the most important national housing programmes that produced more than 4.3 new million housing units across the country between the 1960's and 1980's, through housing cooperatives for low and middle-class households (Bonduki, 1994, 2008). The quality of the architectural design, including the size of rooms and durability of the building components in general, reveals the great attention given to housing for lower-income households in those days.

The apartment in Alto da Lapa, built in the 2000's, is more contemporary and features simplified polymerizing vinyl chloride (PVC) windows. The windows reflect the current residential middle-class market that keeps them to minimum areas. The building is one of the most common middle-class building types erected in São Paulo from the 2000's, which consist of vertical multifamily residential tower buildings in locations where the land is most valued, with reduced room areas and floor to ceiling heights (Alves, 2019).

All the case study buildings selected have in common their architectural relevance within the context of São Paulo's built environment and their analyses will offer a broader indication, and certainly more accurate than if adopting just one typology, in terms of the levels of airtightness found in the city.

\section{Airtightness measurements}

The tested dwellings were occupied, and therefore the simplicity of use of the Pulse test was an added benefit. The Pulse technique is based upon a quasi-steady flow technique and is a rapid test, taking around 6 seconds for each measurement. This equipment causes an instantaneous pressure rise within the building by releasing compressed air into the enclosed space. The volume change of the internal air at the order of $0.004 \%$, then results in a generation of a pulse pressure of approximately $4-8 \mathrm{~Pa}(\mathrm{E}$. 
Cooper et al., 2007; E. Cooper et al., 2016). A variety of measurements must be taken for a range of pressure differentials and Pulse measurements results are quoted at a 4Pa pressure difference. The Pulse unit used is shown in Figure 4. The advantages of the Pulse method in comparison to the traditional steady state pressurisation test, is that it requires no penetration of the building envelope, works at a low pressure (being closer to naturally occurring pressure difference) and importantly in situations of inhabited dwellings, that there is no disruptive high volumetric air flow.

The measurements were carried out from the $20^{\text {th }}$ to the $23^{\text {rd }}$ of March 2017. The buildings were prepared prior to the test following the standard ISO 9972 (BS EN ISO 9972, 2015). This means that all the external windows and doors were closed, the neighbouring apartments had their windows opened and the vents were sealed. Background pressures were measured by the Pulse equipment.

In order to improve the accuracy of the measurement, and to test the replicability of the technique, several tests were carried out in each apartment and an average value was quoted. These tests demonstrated good accuracy in the environment, showing good repeatability in the readings with deviations of up to $\pm 5 \%$ from the average calculated value.

\section{Measurements results}

The airtightness test results are shown in Table 5, quoted at $4 \mathrm{~Pa}$ pressure difference given as $Q_{4}$ for air permeability $\left(\mathrm{m}^{3} \mathrm{~h}^{-1} \mathrm{~m}^{-2}\right)$ and $n_{4}$ for air change rate $\left(\mathrm{h}^{-1}\right)$.

As mentioned, the Pulse airtightness measurements are given at a pressure difference of $4 \mathrm{~Pa}$. At the time of writing there is no published method to convert the Pulse $Q_{4}$ measurement to an infiltration rate, $Q\left(\mathrm{~h}^{-1}\right)$. However, there is an accepted method of converting $Q_{50}$ to $Q$ as used in the UK building regulation (Building Research Establishment, 2013), where infiltration is predicted from airtightness measurements using a ratio (Equation 2), this is based on M. H. Sherman (1987), Kronvall (1978) and Persily (1982) findings.

$$
\text { Equation } 2 \quad Q=Q_{50} / 20
$$

This ratio is then modified by height, shielding and leakiness correction factors. For all the buildings in this study, the first and last correction factors (height and leakiness) are equal to 1, however, for the shielding conditions, all the buildings are well shielded, consequently, the correction factor is 1.2 . 
In order to use the above conversion, the Pulse measurement of $Q_{4}$ had to be converted to a $Q_{50}$ value. Zheng et al. (2019) described a method to extrapolate low-pressure airtightness to high-pressure values based on a power law. The authors acknowledge the errors created from the extrapolation procedures (using Equation 1, and Zheng's methodology), and also from the ratio given in Equation 2. However, it is important to mention that this is the first study in Brazil that measured airtightness in different dwellings, and therefore the use of this was necessary as there was no other context to base the work upon.

In Figure 5 the measured results can be seen, converted to infiltration rate and these are compared against the Brazilian standard NBR 15575 (ABNT, 2013a, 2013b) recommended value.

\section{Airtightness simulations}

The case study buildings were simulated using the dynamic building simulation software EDSL TAS Engineering v. 9.4.2 (EDSL, 2018) to explore the impact of airtightness (infiltration as input used) on the occupants' thermal comfort in São Paulo. Three different levels of infiltration were adopted at ambient pressure: measured levels, recommended levels $\left(1 \mathrm{~h}^{-1}\right)$ as per Brazilian standard NBR 15575 (ABNT, 2013a, 2013b) and a stricter one $\left(0.5 \mathrm{~h}^{-1}\right)$ that reflects levels found in countries where airtightness is considered (Table 6). All the cases were simulated with and without occupancy to understand the impact of occupancy has on the delivery of thermal comfort when combined with a more airtight envelope. Ventilation was adopted only when occupancy was taken into consideration.

Typical conditions of use were assumed in the simulations (Table 7) and these were based on the Brazilian voluntary label RTQ-R (INMETRO, 2012) and ASHRAE (2009). Appliances usage was considered based on affordable Brazilian housing occupancy as per PROCEL INFO (2006), INMETRO (2014) and Tubelo (2016).

\section{Simulation results}

The results of the simulations of the case study buildings focused on the indoor thermal comfort for the rooms with prolonged occupancy (living room and bedrooms) according to the established limits of temperatures $\left(20-27^{\circ} \mathrm{C}\right)$ and relative humidity (below $\left.80 \%\right)$. When simulating occupancy, ventilation was considered according to the windows opening areas, as shown in Table 3. Ventilation was considered as selective (Table 7), meaning that when the outside conditions were not favourable, the 
windows were closed to avoid heat or cold coming inside the building. The concept is that occupants can increase their comfort levels by strategically and adequately managing their ventilation strategies according to the environment conditions.

\section{Higienópolis}

Without occupancy and ventilation, when using the measured airtightness value (converted to infiltration rate at ambient pressure), Higienópolis (Figure 6) had a percentage of thermal comfort estimated to be circa of $66 \%$ of the time. Considering the infiltration levels at $1 \mathrm{~h}^{-1}$ and $0.5 \mathrm{~h}^{-1}$, Higienópolis had the thermal comfort $\left(20-27^{\circ} \mathrm{C}\right)$ slightly increased to up to $69 \%$ and $70 \%$ of the time, an improvement in the thermal comfort of nearly up to $4.5 \%$ and $6 \%$ related to the measured level, respectively. When simulating typical condition of use, at measured infiltration rate $\left(1.82 \mathrm{~h}^{-1}\right)$, the temperatures were up to approximately $71 \%$ of the time within the thermal comfort interval. At typical conditions of use and infiltration levels at $1 \mathrm{~h}^{-1}$ and $0.5 \mathrm{~h}^{-1}$, the comfort levels were moderately increased to up to $77 \%$ (up to $76 \%$ and $78 \%$ in the bedroom) and $81 \%$ of the time, this represented nearly $9 \%$ and $14 \%$ more thermal comfort when compared to the measured infiltration level, respectively.

Looking at relative humidity data, the external relative humidity levels showed to be above $80 \%$ in $43 \%$ of the year. The indoor relative humidity level above the threshold of $80 \%$ showed to be significantly lower, in an unoccupied scenario, it corresponded to just nearly $2 \%$ of the time at measured infiltration rate but this was reduced significantly to negligible levels when infiltration was considered at $1 \mathrm{~h}^{-1}$ and $0.5 \mathrm{~h}^{-1}$. In an occupied and ventilated scenario, the relative humidity level above $80 \%$ was also minimal and corresponded to nearly $1.5 \%$ of the time at measured infiltration level $\left(1.82 \mathrm{~h}^{-1}\right)$, and it was within $1 \%$ range when lower infiltration rates were adopted. No significant impact on the relative humidity levels above $80 \%$ was observed for the infiltration rates investigated under an occupied scenario, and also a relatively steady pattern was observed in the range of $40-60 \%$ of relative humidity.

\section{Pinheiros}

Without occupancy and ventilation, assuming the measured airtightness value (converted to infiltration rate at ambient pressure), Pinheiros (Figure 7) was within thermal comfort for $67 \%$ of the time. At $1 \mathrm{~h}^{-1}$ and $0.5 \mathrm{~h}^{-1}$ of infiltration levels, Pinheiros had its thermal comfort slightly increased to up to $69 \%$ and $72 \%$ of the time, $3 \%$ and $7.5 \%$ more in comparison to the measured level, respectively. With occupancy and ventilation, at measured infiltration rate $\left(1.35 \mathrm{~h}^{-1}\right)$, the thermal comfort corresponded to up to 
approximately $77 \%$ of the time. At infiltration levels of $1 \mathrm{~h}^{-1}$ and $0.5 \mathrm{~h}^{-1}$, the comfort levels consistently increased to up to $79 \%$ and $82 \%$ of the time, circa of $3 \%$ and $6.5 \%$ more thermal comfort when compared to the measured infiltration level, respectively.

The indoor relative humidity levels above the threshold of $80 \%$ were low and corresponded to nearly $2.5 \%$ of the time at measured infiltration rate of $1.35 \mathrm{~h}^{-1}$, when no occupancy and ventilation were assumed. The levels showed a slightly decrease in the percentage of hours above $80 \%$ when infiltration was reduced to $1 \mathrm{~h}^{-1}$ and $0.5 \mathrm{~h}^{-1}$, equivalent to nearly $2 \%$ and $1 \%$, respectively. With the occupancy and ventilation, overall, the levels of relative humidity above $80 \%$ were increased. At measured level (1.35 $\mathrm{h}^{-1}$ ), this represented nearly $3 \%$ of the time and at infiltration rates of $1 \mathrm{~h}^{-1}$ and $0.5 \mathrm{~h}^{-1}$ these were increased moderately to circa of $4 \%$ and $11 \%$ of the time, respectively.

\section{Alto da Lapa}

In an unoccupied scenario and adopting the measured airtightness value (converted to infiltration rate at ambient pressure), Alto da Lapa (Figure 8) had a thermal comfort percentage estimated to be up to $69 \%$ of the time). Considering the infiltration levels at $1 \mathrm{~h}^{-1}$ and $0.5 \mathrm{~h}^{-1}$, higher infiltration values when compared to the measured one of $0.33 \mathrm{~h}^{-1}$, a slightly decreased of the thermal comfort was perceived and this represented to be up to $64.5 \%$ and $67.5 \%$ of the time, nearly $6 \%$ and $2 \%$ less related to the measured value, respectively. In an occupied scenario, at measured infiltration rate $\left(0.33 \mathrm{~h}^{-1}\right)$, the frequency of temperatures within the thermal comfort interval were up to approximately $77 \%$ of the time in Alto da Lapa. At infiltration levels of $1 \mathrm{~h}^{-1}$ and then $0.5 \mathrm{~h}^{-1}$, as expected, the comfort levels decreased to nearly $73 \%$ and $76 \%$, circa of $5 \%$ and $1.5 \%$ lower related to the measured level, respectively.

In terms of relative humidity, in an occupied scenario, the levels above $80 \%$ threshold corresponded to nearly $3 \%$ for the measured infiltration level of $0.33 \mathrm{~h}^{-1}$ and were slightly increased to $4.5 \%$ and $3.5 \%$ due to the increase of infiltration levels to $1 \mathrm{~h}^{-1}$ and $0.5 \mathrm{~h}^{-1}$, respectively. In an occupied and ventilated scenario, the frequency of relative humidity above $80 \%$ showed an inverse pattern in comparison to the unoccupied scenario and this meant an increase of the time above the threshold of $80 \%$ for lower infiltration rates. The relative humidity was above $80 \%$ in nearly $17 \%$ of the time for the measured infiltration rate, $6 \%$ of the time for infiltration of $1 \mathrm{~h}^{-1}$ and $11 \%$ of the time for infiltration of $0.5 \mathrm{~h}^{-1}$, respectively. 


\section{Discussion}

The novelty of this work lies on the collection of airtightness values for the first time in Brazil using the innovative Pulse test method and in the exploration of the contribution of this design parameter to comfort in buildings in Sao Paulo though the use of dynamic building simulation. Whilst the levels of airtightness were never measured, also rests a discussion about the impact of airtightness on the thermal comfort in climates where natural ventilation is vastly adopted. This work makes an addition to this knowledge, contributing to a vastly underdeveloped research area.

Even though the Brazilian construction sector overlook the concept of airtightness and its benefits on the delivery of better levels of indoor thermal comfort, the residential construction sector specifically utilises materials that are airtight themselves. Walls are normally plastered, and slabs are usually made by cast-in-place concrete in the multifamily residential buildings, as found in the case study buildings.

However, whilst the building components seemed to contribute to achieve lower airtight levels, the fitted windows seemed to be the most leakage and thermal bridging building component of the overall construction in the cases investigated. Brazilian windows are mostly single glazed, and frames are made of wood, steel, aluminium, with no use of warm spacers. The use of PVC framed windows is relatively new, and those of better quality and more airtight are still limited to upper-classes due costs constraints. This seems to be one of the reasons why the building in Alto da Lapa, which use the PVCframed windows demonstrate to be tightest apartment according to the measurements. Also, the reason why the 1960' apartment in Higienópolis, which is fitted with unsealed steel framed windows, showed the highest measured airtightness value.

Only one of the measured apartments met the recommended infiltration rate of $1 \mathrm{~h}^{-1}$ (ABNT, 2013a, 2013b), the two other apartment units had nearly $35 \%$ and $80 \%$ values higher than the standard recommends. This seemed to suggest a wide range of values and discrepancies among the Brazilian building stock, that requires further investigation.

The analysis of thermal comfort, limited to dynamic simulations at established comfort temperatures limits, showed that lower airtight values contributed to achieve better indoor comfort levels, mostly by mitigating the cold temperatures. Figure 9 illustrates the case study buildings for temperature limits of $18^{\circ} \mathrm{C}$ and $20^{\circ} \mathrm{C}$, for unoccupied (represented by solid lines) and occupied (represented by stripped 
lines) scenarios. It is worth mentioning that because the climate of São Paulo does not have extremes of high temperatures in their climatic files, the benefits of limited infiltration on reducing thermal discomfort due to the high temperatures were not observed. It is, however, important to further investigate this in the future considering climate change predictions.

At infiltration rate of $1 \mathrm{~h}^{-1}$, as suggested by the Brazilian standard, the thermal discomfort due to low temperatures was reduced to up to nearly half in Higienópolis for an occupied scenario in comparison to the measured rate of $1.82 \mathrm{~h}^{-1}$ for a $18^{\circ} \mathrm{C}$ reference. In Alto da Lapa, the adoption of the infiltration rate as suggested by the Brazilian standard would double the thermal discomfort of temperatures lower than $18^{\circ} \mathrm{C}$ compared to the measured infiltration rate of $0.33 \mathrm{~h}^{-1}$. At lower infiltration rates, the frequency of temperatures below $18^{\circ} \mathrm{C}$ were greatly reduced, showing that the temperatures were able to stay most of the time within the thermal comfort or slightly below the lower thermal comfort limit (between $18^{\circ} \mathrm{C}$ and $20^{\circ} \mathrm{C}$ ). This demonstrated the importance of the airtightness as a design parameter in the context of São Paulo and the importance that low levels of infiltration rates have on the delivery of thermal comfort in this climate, considering the assumptions and comfort limits simulated.

The indoor relative humidity levels, illustrated in Figures 6-8, showed to be negatively impacted by the reduction of the infiltration rates. However, this impact most of the time corresponded to be lower than or nearly $10 \%$ of the year, which was immensely lower than the outdoor levels of relative humidity for the threshold of $80 \%$. This, however, showed to be more significant in Pinheiros and Alto da Lapa and negligible in Higienópolis, which might be attributed to the spacious size of the Higienópolis apartment.. This is because large floor areas at a typical occupancy rate result in smaller heat gains (sensible and latent) per square metre, which will then impact differently in terms of relative humidity. It needs to be noted that, inevitably, the use of ventilation will also increase the levels of moisture inside the building as it tends to follow the external condition. The impact of relative humidity in the case of more airtight buildings must be further investigated, mainly in the context of Brazilian dwellings of limited size and high occupancy rate, mostly for low and middle-income households.

\section{Conclusions}


Airtightness measurements conducted for the first time in Brazil using the innovative Pulse test and representative architectural examples showed a high variability of the air change rate across the case study buildings, varying from $1 \mathrm{~h}^{-1}$ to $5.7 \mathrm{~h}^{-1}$ (equivalent to infiltration rates varying from 0.33 to $1.82 \mathrm{~h}^{-}$ 1). The measurement results (converted to infiltration) suggested that the Brazilian Standard NBR 15575 (ABNT, 2013a, 2013b) might be wrongly estimating the infiltration rates of Brazilian buildings, assuming that these would correspond to nearly $1.0 \mathrm{~h}^{-1}$. In one of the buildings measured, infiltration rate showed to be nearly $80 \%$ bigger than the standard reference value. Similarly, the lowest value measured was nearly $70 \%$ smaller than the standard recommends. The high variability on the levels measured and its discrepancies with the recommended value indicated the need for further investigation considering a much larger building's sample, especially if the delivery of the predicted thermal performance is aimed in Brazilian buildings.

The results of the occupants' thermal comfort analytical investigation, conducted through the use of dynamic building simulations, considering an occupied and ventilated scenario, supported the argument that lower infiltration rate, matching the one suggested by the Brazilian standard $\left(1 \mathrm{~h}^{-1}\right)$, delivered an increase of thermal comfort of up to $9 \%$ considering as reference the building that had the highest infiltration rate measured. For this case study building, stricter infiltration rate at $0.5 \mathrm{~h}^{-1}$ was estimated to deliver circa of up to $14 \%$ more thermal comfort than the measured level. However, for the building that had the lowest infiltration rate, the recommended standard infiltration rate would decrease the thermal comfort in $5 \%$ compared to the measured infiltration rate. The results consistently indicated that lower levels of infiltration would deliver better indoor thermal comfort levels for the context investigated.

Relative humidity levels showed to be positively impacted by an airtight envelope when no occupancy was considered but slightly negatively when occupancy and ventilation were considered. However, this does not show to be an issue in the climate investigated, and high levels of relative humidity were immensely lower than those outdoors. Further investigation needs to be conducted to evaluate the impact of airtight envelopes on relative humidity for typical occupancy without the consideration of ventilation, especially in compact and over occupied dwellings where internal gains are more representative.

The authors acknowledge that the sample size ( 3 apartments) was a limitation of this work and plan to expand this number in subsequent projects. More measurements should be conducted to examine the 
current levels of airtightness in a variety of other Brazilian multifamily residential building typologies, in

São Paulo and in other regions of the country. The findings seemed to suggest that newer buildings have progressively been built with higher levels of airtightness over the years and could potentially deliver greater levels of thermal comfort to the occupants when compared to the older buildings, a hypothesis that could not be confirmed with a sample of this size. This hypothesis will need to be explored through larger samples in subsequent studies.

Nonetheless, one should keep in mind that airtightness alone is not an all-encompassing solution to improve thermal comfort in buildings in São Paulo. Given the demonstrated impact of this variable on the delivery of the indoor thermal comfort in multifamily residential buildings, the authors suggest that airtightness should be considered as one of the key building elements in the design and construction in subtropical Brazilian climates. This work, although conducted in the city of São Paulo, Brazil, can help inform about the airtightness quantifying methods and its thermal comfort contribution in other countries of similar climate, building typologies and construction components.

\section{References}

ABNT. (2013a). NBR 15575-1: Residential buildings - Performance - Part 1: General requirements. Associação Brasileira de Normas Técnicas (ABNT).

ABNT. (2013b). NBR 15575-4: Residential buildings - Performance - Part 4: Requirements for internal and external wall systems. Associação Brasileira de Normas Técnicas (ABNT).

ABNT. (2013c). NBR 15575-5: Residential buildings - Performance - Part 5: Requirements for roofing systems. Associação Brasileira de Normas Técnicas (ABNT).

Alves, C. (2019). A produção recente de edifícios residenciais em São Paulo: desempenho e conforto térmico no contexto climático em transição [The recent production of residential buildings in São Paulo: performance and thermal comfort in the transition climate context], University of São Paulo].

Alves, C., Duarte, D., \& Goncalves, F. (2016). Residential buildings' thermal performance and comfort for the elderly under climate changes context in the city of São Paulo, Brazil. Energy and Buildings, 114, 62-71. https://doi.org/10.1016/i.enbuild.2015.06.044

ANSI/ASHRAE Standard 55. (2010). Thermal environmental conditions for human occupancy. American Society of Heating, Refrigerating and Air Conditioning Engineers (ASHRAE).

ASHRAE. (2009). ASHRAE Handbook - Fundamentals. American Society of Heating, Refrigerating and Air Conditioning Engineers (ASHRAE)

ASTM. (2019). Standard test method for determining air leakage rate by fan pressurization. Designation: E779-19. American Society for Testing and Materials (ASTM).

Baracu, T., Badescu, V., Teodosiu, C., Degeratu, M., Patrascu, M., \& Streche, C. (2017). Consideration of a new extended power law of air infiltration throughthe building's envelope providing estimations of the leakage area. Energy and Buildings, 149, 400-423. https://doi.org/10.1016/i.enbuild.2017.04.055

Bonduki, N. (1994). Origens da habitação social no Brasil [Origins of social housing in Brazill. Análise Social, vol. XXIX(127), 711-732. http://analisesocial.ics.ul.pt/documentos/1223377539C9uKS3pp5Cc74XT8.pdf

Bonduki, N. (2008). Política habitacional e inclusão social no Brasil: Revisão histórica e novas perspectivas no governo Lula [Housing policy and social inclusion in Brazil: Historical review and new perspectives in Lula's government]. Arq.urb - Revista eletrônica de Arquitetura e Urbanismo, 1, 70-104. https://revistaarqurb.com.br/arqurb/article/view/81/75

BS EN ISO 9972. (2015). Thermal performance of buildings - Determination of air permeability of buildings - Fan pressurization method. The British Standards Institution (BSI).

Building Research Establishment. (2013). The Government's standard assessment procedure for energy rating of dwellings. 2012 edition. Building Research Establishment on behalf of the Deparment of Energy and Climate Change. 
Candido, C., Lamberts, R., De Dear, R., Bittencourt, L., \& De Vecchi, R. (2011). Towards a Brazilian standard for naturally ventilated buildings: guidelines for thermal and air movement acceptability. Building Research \& Information, 39(2), 145-153. https://doi.org/10.1080/09613218.2011.557858

Chan, W. R., Nazaroff, W., Price, P. N., Sohn, M., \& Gadgil, A. (2005). Analyzing a database of residential air leakage in the United States. Atmospheric Environment, 39, 3445-3455. https://doi.org/10.1016/j.atmosenv.2005.01.062

Chiu, Y., \& Etheridge, D. (2002). Calculations and notes on the quadratic and power law equations for modelling infiltration. International Journal of Ventilation, 1(1), 65-77.

Cooper, E., Etheridge, D., \& Smith, S. J. (2007). Determining the adventitious leakage of buildings at low pressure. Part 2: Pulse technique. Building Services Engineers Research Technology, 28, 81-96. https://doi.org/10.1177/0143624406072331

Cooper, E., Zheng, X., Wood, C., Gillott, M., Tetlow, D., Riffat, S., \& De Simon, L. (2016). Field trialling of a pulse airtightness tester in a range of UK homes. International Journal of Ventilation, 18(1), 1-18. https://doi.org/10.1080/14733315.2016.1252155

EDSL. (2018). TAS Engineering Software (Version 9.4.2). Environmental Design Solutions Limited (EDSL).

Emmerich, S., Persily, A., \& McDowell, T. (2005). Impact of infiltration on heating and cooling loads in US office buildings. 26th AIVC (Air Infiltration and Ventilation Centre) Conference, Brussels, Belgium.

EPE. (2018). Nota Técnica EPE 030/2018 - Uso de ar condicionado no setor residencial Brasileiro: Perspectivas e contribuições para o avanço em eficiência energética [Technical Note EPE 030/2018 - The use of air conditioning in the Brazilian residential sector: Perspectives and contributions to the advancement in energy efficiency. (http://epe.gov.br/pt/publicacoes-dados-abertos/publicacoes/nota-tecnica-epe-030$\underline{2018}$.

Etheridge, D. (2015). A perspective on fifty years of natural ventilation research. Building and Environment, 91, 5169. https://doi.org/10.1016/j.buildenv.2015.02.033

Feijó-Muñoz, J., González-Lezcano, A., Poza-Casado, I., Padilla-Marcos, M. A., \& Meiss, A. (2019). Airtightness of residential buildings in the Continental area of Spain. Building and Environment, 148, 299-308. https://doi.org/10.1016/. buildenv.2018.11.010

Fernández-Agüera, J., Domínguez-Amarillo, S., Alonso, C., \& Martín-Consuegra, F. (2019). Thermal comfort and indoor air quality in low-income housing in Spain: The influence of airtightness and occupant behaviour Energy \& Buildings, 199, 102-114. https://doi.org/10.1016/i.enbuild.2019.06.052

Fernández-Agüera, J., Domínguez-Amarillo, S., Sendra, J. J., \& Suárez, R. (2016). An approach to modelling envelope airtightness in multi-family social housing in Mediterranean Europe based on the situation in Spain. Energy and Buildings, 128, 236-253. https://doi.org/10.1016/j.enbuild.2016.06.074

Fernández-Agüera, J., Domínguez-Amarillo, S., Sendra, J. J., Suárez, R., \& Oteiza, I. (2019). Social housing airtightness in Southern Europe. Energy \& Buildings, 183, 377-391. https://doi.org/10.1016/j.enbuild.2018.10.041

Ford, B., Schiano-Phan, R., \& Zhongcheng, D. (2007). The Passivhaus standard in European warm climates: design guidelines for comfortable low energy homes. Part 3: Comfort, climate and passive strategies. (

Ghisi, E., Gosch, S., \& Lamberts, R. (2007). Electricity end-uses in the residential sector of Brazil. Energy Policy, 35(8), 4107-4120. https://doi.org/10.1016/i.enpol.2007.02.020

Givoni, B. (1992). Comfort, climate analysis and building design guidelines. Energy and Buildings, 18, 11-23.

Hassan, O. (2013). An alternative method for evaluating the air tightness of building components. Building and Environment, 67, 82-86. https://doi.org/10.1016/i.buildenv.2013.05.007

HM Government. (2002). L1 Conservation of fuel and power in dwellings. Ministry of Housing, Communities \& Local Government.

HM Government. (2006). L1A Conservation of fuel and power in new dwellings. Ministry of Housing, Communities \& Local Government

Humphreys, M., Rijal, H., \& Nicol, J. (2013). Updating the adaptive relation between climate and comfort indoors; new insights and an extended database. Building and Environment, 63, 40-55. https://doi.org/10.1016/j.buildenv.2013.01.024

IBGE. (2017). Estimativas da população de residentes no Brasil e unidades da Federação com dados de referência em $1^{\circ}$ de julho de 2017 [Estimates of the resident population in Brazil and Federation units with reference data on 1st July 2017]. Instituto Brasileiro de Geografia e Estatística (IBGE). Retrieved 26 June 2018 from $\mathrm{ftp}: / / \mathrm{ftp}$.ibge.gov.br/Estimativas de Populacao/Estimativas 2017/estimativa dou 2017.pdf

INMET. (2018). Normais climatológicas do Brasil de 1981-2010 [Brazilian climatological norms from 1981-2010]. I. N. d. M. (INMET)

INMETRO. (2012). Regulamento técnico da qualidade para o nível de eficiência energética edificações residenciais (RTQ-R). Portaria $\mathrm{n}^{\circ} 18$ de 16 de Janeiro de 2012 [Technical quality regulation for the level of energy efficiency in residential buildings (RTQ-R). Ordinance No. 18 of 16 January 2012]. Instituto Nacional de Metrologia, Qualidade e Tecnologia (INMETRO)

INMETRO. (2014). Tabelas de consumo de energia/eficiência energética [Tables of energy consumption/energy efficiency]. Instituto Nacional de Metrologia, Qualidade e Tecnologia (INMETRO) Retrieved 10 August 2020 from http://www.inmetro.gov.br/consumidor/tabelas.asp

lordache, V., \& Catalina, T. (2012). Acoustic approach for building air permeability estimation. Building and Environment, 57, 18-27. https://doi.org/10.1016/i.buildenv.2012.04.008 
Ji, W., Luo, M., Cao, B., Zhu, Y., Geng, Y., \& Lin, B. (2018). A new method to study human metabolic rate changes and thermal comfort in physical exercise by $\mathrm{CO} 2$ measurement in an airtight chamber. Energy and Buildings, 177, 402-412. https://doi.org/doi.org/10.1016/i.enbuild.2018.08.018

Ji, Y., \& Duanmu, L. (2017). Airtightness field tests of residential buildings in Dailan, China. Building and Environment, 119, 20-30. https://doi.org/doi.org/10.1016/j.buildenv.2017.03.043

Jones, B., Lowe, R., Davies, M., Chalabi, Z., Das, P., \& Ridley, I. (2014). Modelling uniformly porous facades to predict dwelling infiltration rates. Building Services Engineering Research \& Technology, 35(4), 408-416. https://doi.org/10.1177/0143624413499354

Khemet, B., \& Richman, R. (2020). Towards a methodological approach to builder specific, preconstruction airtightness estimates for light-framed, detached, low-rise residential buildings in Canada. Journal of Building Engineering, 29. https://doi.org/10.1016/j.jobe.2019.101140

Kraniotis, D., Thiis, T., \& Aurlien, T. (2014). A Numerical study on the impact of wind gust frequency on air exchanges in buildings with variabhle external and internal leakages. Buildings, 4(1), 27-42. https://doi.org/10.3390/buildings4010027

Kronvall, J. (1978). Testing of houses for air leakage using a pressure method. ASHRAE Transactions.

LabEEE. (2010). Analysis Bio Software (Version 2.2). Laboratório de Eficiência Energética em Edificações (LaBEEE).

Lamberts, R. (2008). Trends in Brazilian building ventilation market and drivers for change. Trends in national building ventilation market and drivers for change, Ghent, Belgium.

Love, J., Wingfield, J., Smith, A. Z. P., Biddulph, P., Oreszczyn, T., Lowe, R., \& Elwell, C. A. (2017). 'Hitting the target and missing the point': Analysis of air permeability data for new UK dwellings and what it reveals about the testing procedure. Energy and Buildings, 155, 88-97. https://doi.org/10.1016/i.enbuild.2017.09.013

Mattsson, B., \& Claesson, J. (2007). A transient pressurization method for measurements of airtightness. Journal of Building Physics, 31(1), 35-53. https://doi.org/10.1177/1744259107079021

Ministério das Cidades. (2014). Programa Minha Casa Minha Vida/FAR: Especificações Mínimas Casa [My House, My Life housing programme: Minimum house requirements]. Ministério das Cidades. Retrieved 06 January 2015 from http://www.cidades.gov.br/images/stories/ArquivosSNH/ArquivosPDF/Especificacoes/especificacoes ca sa port168.pdf

Mortensen, L. H., \& Bergsøe, N. C. (2017). Air tightness measurements in older Danish single-family houses. Energy Procedia, 132, 825-830. https://doi.org/10.1016/i.egypro.2017.10.016

Nicol, F. (2004). Adaptive thermal comfort standards in the hot-humid tropics. Energy and Buildings, 36, 628-637.

Nicol, J., Humphreys, M., \& Roaf, S. (2012). Adaptive thermal comfort: principles and practice. Routledge.

Oliveira, A. P., Silveria, L. C., Nofoente, J. F., Sanchez, M. P., Tito, J. V., Codato, G., Marques Filho, E. P., Pereira, M. M. R., \& Ribeiro, F. N. D. (2018). Observational Investigation of the Urban Heat Island in the Metropolitan Region of São Paulo City. 10th International Conference on Urban Climate Jointly with 14th Symposium on the Urban Environment, New York.

Orme, M., \& Leksmono, N. (2005). AIVC guide 5: Ventilation modelling data guide. I. E. A. (AIVC)

Pacheco, M. (2013). Ventilação natural e climatização artificial: Crítica ao modelo superisolado para residência de energia zero em Belém e Curitiba [Natural ventilation and HVAC: Criticism of the super-isolated model for zero energy homes in Belém and Curitiba], Universidade Federal de Santa Catarina].

Pacheco, M., \& Lamberts, R. (2013). Assessment of technical and economical viability for large-scale conversion of single family residential buildings into zero energy building in Brazil: Climatic and cultural considerations. Energy Policy, 63, 716-725. https://doi.org/10.1016/i.enpol.2013.07.133

Parkinson, T., De Dear, R., \& Brager, G. (2020). Nudging the adaptive thermal comfort model. Energy and Buildings, 206. https://doi.org/10.1016/i.enbuild.2019.109559

Patrascu, M., Baracu, T., Badescu, V., Birsan, M.-V., Catalin, T., Degeratu, M., Avram, E. R., Udrea, M., Calancea, L., \& Mesteru, C. (2018). Modeling air leakage in buildings caused by the cyclic variation of the atmospheric pressure. Building Services Engineering Research and Technology, 39(4), 430-462. https://doi.org/10.1177/0143624417749536

PBMC. (2013). Executive Summary: The scientific basis of climate change - Contribution from the working group 1 to the first national assessment report of the Brazilian Panel on Climate Change (GT1 RAN1 PBMC). P. B. d. M. C. (PBMC)

Persily, A. (1982). Understanding air infiltration in homes, Princeton University].

Prignon, M., \& Van Moeseke, G. (2017). Factors influencing airtightness and airtightness predictive models: A literature review. Energy and Buildings, 146, 87-97. https://doi.org/10.1016/i.enbuild.2017.04.062

PROCEL INFO. (2006). Equipamentos [Equipment]. Centrais Elétricas Brasileiras S.A. (ELETROBRAS). Retrieved 10 August 2020 from http://www.procelinfo.com.br/main.asp?View=\%7bE6BC2A5F-E787-48AF-B485439862B17000\%7d

Ramos, N. M., Almeida, R., Curado, A., Fereira, P., Manuel, S., \& Maia, J. (2015). Airtightness and ventilation in a mild climate country rehabilitated social housing buildings - What users want and what they get. Building and Environment, 92, 97-110. https://doi.org/10.1016/j.buildenv.2015.04.016

RDH Building Engineering Ltd. (2013). Air Leakage Control in Multi-Unit Residential Buildings. C. M. a. H. Corporation 
Rijal, H., Humpreys, M., \& Nicol, F. (2015). Adaptive thermal comfort in Japanese houses during the summer season: Behavioral adaptation and the effect of humidity. Buildings, 5, 1037-1054. https://doi.org/10.3390/buildings5031037

Roriz, M. (2012). Arquivos climáticos em formato EPW [Climatic files in EPW format].http://www.labeee.ufsc.br/downloads/arquivos-climaticos/formato-epw

Salehi, A., Torres, I., \& Ramos, A. (2017). Experimental analysis of building airtightness in traditional residential Portuguese buildings. Energy and Buildings, 151, 198-205. https://doi.org/10.1016/i.enbuild.2017.06.037

Santamouris, M., \& Asimakopoulos. (1996). Passive Cooling of Buildings. James \& James.

Serapião, F. (2014). Moderno nas Alturas [Modern in the Heights]. Revista Monólito, Higienópolis, 19, 14-26.

Sherman, M., \& Dickinson, B. (1985). The predicition of air infiltration. CLIMA 2000, Copenhagen, Denmark.

Sherman, M., \& Palmiter, L. (1995). Uncertainties in fan pressurization measures. ASTM: Airflow Performance Conference 10/93 LBL-32115.

Sherman, M. H. (1987). Estimation of infiltration from leakage and climate indicators. Energy and Buildings, 10(1), 81-86. https://doi.org/10.1016/0378-7788(87)90008-9

Sherman, M. H. (1991, 22-26 September). Single-zone stack-dominated infiltration modelling. 12th Air Infiltration and Ventilation Conference, Ottawa, Canada.

Triana, M., Roberto Lamberts, R., \& Sassiba, P. (2018). Should we consider climate change for Brazilian social housing? Assessment of energy efficiency adaptation measures. Energy and Buildings, 158, 1379-1392. https://doi.org/10.1016/i.enbuild.2017.11.003

Tubelo, R. (2016). The Application of the Fabric First Approach to Improve Thermal Comfort and Energy Efficiency in Affordable Housing in Southern Brazil, University of Nottingham].

Tubelo, R., Rodrigues, L., Gillott, M., \& Gonçalves Soares, J. C. (2018). Cost-effective envelope optimisation for social housing in Brazil's moderate climates zones. Building and Environment, 133, 213-227. https://doi.org/10.1016/j.buildenv.2018.01.038

Uzum, M., \& Gonçalves, J. C. S. (2020). The thermal performance of residential compact housing in tall buildings: an analytical examination for the retrofit of facades in the densified city center of São Paulo. Architectural Science Review. https://doi.org/10.1080/00038628.2020.1748870

Varshney, K., Rosa, J. E., Shapiro, I., \& Scott, D. (2013). Air-infiltration measurements in buildings using sound transmission loss through small apertures. International Journal of Green Energy, 10(5), 482-493. https://doi.org/10.1080/15435075.2012.675603

Veiga, E., \& Burgarelli, R. (2016, 16 April 2017). São Paulo é uma cidade dos anos 70: 1/4 dos imóveis é daquela década [São Paulo is a city of the 1970's: $1 / 4$ of the properties are from that decade. $O$ Estado de $S$. Paulo (Estadão). https://sao-paulo.estadao.com.br/noticias/geral,sao-paulo-e-uma-cidade-dos-anos-7014-dos-imoveis-e-daquela-decada, 70001739800

Vinha, J., Manelius, E., Korpi, M., Salminen, K., Kurnitski, J., Kiviste, M., \& Laukkarinen, A. (2015). Airtightness of residential buildings in Finland. Building and Environment, 93, 128-140. https://doi.org/10.1016/j.buildenv.2015.06.011

Walker, I. S., \& Wilson, D. J. (1990). AIM-2: The Aberta air infiltration model. T. U. o. Alberta. https://www.aivc.org/sites/default/files/airbase 3705.pdf

Walker, I. S., \& Wilson, D. J. (1998). Field validation of algebraic equations for stack and wind driven air infiltration calculations. ASHRAE HVAC\&R Research Journal, 4(2), 1-22.

Watanabe, Y., Kobayashi, H., \& Utsumi, Y. (1999, 13-15 September 1999). Development of validation of AC pressurization measuring of leakage area of houses. Buildings Simulation '99, Sixth International IBPSA Conference, Kyoto, Japan.

Zheng, X., Cooper, E., Mazzon, J., Wallis, I., \& Wood, C. (2019). Experimental insights into the airtightness measurement of a house-sized chamber in a sheltered environment using blower door and pulse methods. Building and Environment, 162. https://doi.org/10.1016/j.buildenv.2019.106269 